\title{
Evaluasi Aplikasi Media Pembelajaran Statistika Dasar Menggunakan Metode Usability Testing
}

\author{
Vederico Pitsalitz Sabandar \\ Magister Teknik Informatika \\ Universitas Amikom Yogyakarta \\ vedericopitsalitzsabandar@yahoo.co.id
}

\author{
Harry Budi Santoso \\ Fakultas Ilmu Komputer \\ Universitas Indonesia \\ harrybs@cs.ui.ac.id
}

\begin{abstract}
Abstrak - Dalam mengembangkan suatu sistem, suatu prinsip utama yang dijadikan ukuran keberhasilan dari sistem tersebut ialah usability. Penelitian ini bertujuan untuk mengevaluasi Aplikasi Media Pembelajaran Statistika Dasar (AMPSD) serta memperoleh rekomendasi guna pengembangan selanjutnya. Evaluasi yang dilakukan, berfokus pada aspek usability yang terdiri dari efektivitas, efisiensi, dan kepuasan pengguna. Selanjutnya, rekomendasi yang diperoleh kemudian disusun menggunakan prinsip desain interaksi. Penelitian ini menggunakan metode usability testing dengan target pengujian terdiri dari kelompok dosen dan mahasiswa sebanyak 30 responden. Selanjutnya, untuk mengukur tingkat kepuasan pengguna, digunakan kuesioner System Usability Scale (SUS). Hasil evaluasi yang dilakukan, menunjukkan bahwa AMPSD telah memenuhi tiga aspek usability, yaitu efektivitas, efisiensi, dan kepuasan pengguna. Hasil analisis terhadap tingkat efektivitas dan efisiensi penggunaan aplikasi menunjukkan bahwa baik pada kelompok dosen maupun mahasiswa, sukses (tidak mengalami kegagalan) dalam menyelesaikan tugas dengan lamanya waktu yang dibutuhkan dikategorikan sangat cepat. Selanjutnya, hasil analisis terhadap tingkat kepuasan pengguna menggunakan kuesioner SUS, menunjukkan bahwa aplikasi tersebut dapat diterima (acceptable). Rekomendasi yang diperoleh yaitu terkait dengan tampilan interface dan konten yang terdapat pada halaman beranda, game education, dan materi, dimana perlu dirancang kembali agar lebih memudahkan user dan tidak menimbulkan kejenuhan selama menggunakan aplikasi tersebut.
\end{abstract}

Kata Kunci : Efektivitas, Efisiensi, Kepuasan Pengguna, Rekomendasi, System Usability Scale (SUS), Usability.

\section{PENDAHULUAN}

Perkembangan terhadap teknologi informasi dan komunikasi yang semakin maju dan pesat, telah menjadi acuan terhadap manusia untuk dapat membuat berbagai macam peralatan sebagai alat bantu dalam menjalankan berbagai aktivitas [1]. Salah satu alat bantu yang dapat digunakan dalam dunia pendidikan, yaitu penggunaan media pembelajaran. Penggunaan media pembelajaran adalah salah satu faktor yang mempunyai pengaruh cukup besar dalam proses pembelajaran dalam pencapaian hasil belajar [2]. Seperti yang diungkapkan oleh Vebrianto, bahwa menggunakan berbagai media pembelajaran dapat membantu pembelajaran peserta didik, sehingga meningkatkan pengetahuan peserta didik dan mengembangkan sikap dan keterampilan mereka dalam sains [3]. Aplikasi Media Pembelajaran Statistika Dasar (AMPSD) merupakan suatu produk pembelajaran pertama yang dikembangkan pada Program Studi Pendidikan Fisika FKIP UNPATTI Ambon untuk mata kuliah Statistika Dasar sebagai alternatif pembelajaran dengan tujuan untuk mempermudah pendidik (dosen) dalam melakukan proses belajar mengajar serta membantu peserta didik (mahasiswa) dalam belajar, baik di kelas maupun belajar secara mandiri. Aplikasi tersebut dapat dijalankan pada tampilan desktop PC, laptop, maupun notebook dengan tipe file yang dihasilkan dalam bentuk .exe, sehingga memungkinkan pengguna untuk mudah menjalankannya. Akan tetapi, selama penggunaannya, aplikasi tersebut hanya dibuat untuk meningkatkan prestasi dan hasil belajar serta meningkatkan motivasi dan minat belajar mahasiswa tanpa memperhatikan kebutuhan user yang berdampak pada tujuan dari aplikasi tersebut, yaitu mudah digunakan, dapat memberi manfaat, bertahan lama dalam penggunaanya, dapat membuat aplikasi tersebut populer dalam waktu lama dan luas penggunaannya.

Prinsip utama yang dijadikan ukuran keberhasilan suatu sistem guna memastikan bahwa tujuan dari sistem tersebut, dapat dicapai dengan memperhatikan kebutuhan user adalah usability. Usability berasal dari kata usable yang berarti dapat digunakan dengan baik. Seperti yang diungkapkan oleh Rubin dan Chisnell, yang menyatakan bahwa sesuatu dapat dikatakan berguna dengan baik apabila kegagalan dalam penggunaannya dapat dihilangkan atau diminimalkan serta memberi manfaat dan kepuasan kepada pengguna [4]. Sementara itu, menurut ISO 9241-11 tahun 1998 usability didefinisikan sebagai sejauh mana suatu produk dapat digunakan oleh pengguna tertentu berdasarkan efektivitas, efisiensi dan kepuasan dalam konteks penggunaan guna mencapai tujuan yang ditentukan [5]. Dengan demikian, dapat diketahui bahwa usability memiliki tiga aspek, yaitu efektivitas, efisiensi, dan kepuasan pengguna. Seperti yang dijelaskan oleh Nielsen bahwa suatu aplikasi disebut usable jika fungsi-fungsinya dapat dijalankan secara efektif, efisien, 
dan memuaskan [6]. Selanjutnya, ketiga aspek usability tersebut dapat dijelaskan sebagai berikut [7]:

a. Efektivitas (effectiveness), mengacu pada sejauh mana produk berperilaku dengan cara yang diharapkan user dan kemudahan yang dapat digunakan pengguna untuk melakukan apa yang diinginkan. Komponen ini biasanya diukur secara kuantitatif dengan tingkat kesalahan.

b. Efisiensi (efficiency), adalah kecepatan di mana tujuan user dapat dicapai secara akurat dan lengkap dan biasanya merupakan ukuran waktu.

c. Kepuasan (satisfaction), mengacu pada persepsi, perasaan, dan pendapat user tentang produk. Biasanya, user diminta untuk menilai dan memberi peringkat produk yang mereka coba, dan hal ini sering dapat mengungkapkan penyebab dan alasan masalah yang terjadi.

Untuk mengatasi permasalahan tersebut, maka dalam penelitian ini akan dilakukannya suatu evaluasi terhadap AMPSD dari segi usability yang bertujuan untuk mengukur efektivitas dan efisiensi dalam penggunaannya, serta mengetahui sejauh mana aplikasi tersebut dapat memberikan kepuasan kepada user sebagai alternatif keputusan untuk kelangsungan aplikasi tersebut. Evaluasi usability berfokus pada seberapa baik user dapat belajar dan menggunakan produk untuk mencapai tujuan serta menilai sejauh mana sistem interaktif mudah dan menyenangkan untuk digunakan [8]. Ini juga mengacu pada seberapa puas pengguna dengan proses itu. Untuk itu, adapun pendekatan yang digunakan dalam penelitian ini, yaitu dengan menggunakan metode usability testing. Metode usability testing merupakan cara terbaik untuk mengevaluasi aplikasi atau suatu produk dengan mengujinya langsung berdasarkan pengalaman pengguna (user experience) [9]. Hasil akhir dari evaluasi AMPSD yang dilakukan, diharapkan dapat memberikan tingkat usability yang baik serta memperoleh rekomendasi perbaikan guna menghasilkan aplikasi yang lebih baik.

\section{METODOLOGI PENELITIAN}

A. Jenis dan Pendekatan Penelitian

1) Jenis Penelitian

Jenis penelitian yang dilakukan merupakan jenis penelitian evaluatif dan bersifat deskriptif yang bertujuan untuk menjelaskan dan mengukur keberhasilan suatu program, produk atau kegiatan tertentu dan membandingkan hasil pengukuran dan pengumpulan data dengan standar yang digunakan untuk mengetahui suatu kegiatan yang dilakukan itu layak atau tidak, relevan atau tidak, efisien dan efektif atau tidak [10].

2) Pendekatan Penelitian

a) Metode Evaluasi Usability

Adapun pendekatan yang dapat digunakan untuk melakukan evaluasi usability, yaitu dengan menggunakan metode usability testing. Usability testing merupakan salah satu cara untuk mengevaluasi suatu produk atau layanan dengan mengujinya kepada pengguna yang diwakilkan [8]. Untuk itu, terdapat langkah-langkah yang perlu dilakukan dalam usability testing yang terdiri dari empat langkah, yaitu antara lain (1) mengidentifikasi target pengujian; (2) membuat usability testing task; (3) melakukan usability testing; dan (4) analisis usability testing [9].

\section{b) Metode Rekomendasi Perbaikan}

Rekomendasi perbaikan bertujuan untuk menghasilkan suatu prototype perbaikan guna pengembangan selanjutnya. Prototype perbaikan tersebut, disusun berdasarkan prinsip desain interaksi (interaction design) yaitu aturan dasar yang digunakan untuk membuat sebuah antarmuka (interface) yang baik bagi pengguna. Menurut Shneiderman, aturan mendasar tersebut dikategorikan menjadi delapan aturan emas desain antarmuka Shneiderman (Shneiderman's 8 Golden Rules of Interface Design) diantaranya, yaitu [11]:

Tabel 1. Shneiderman's 8 Golden Rules of Interface Design.

\begin{tabular}{cl}
\hline No & \multicolumn{1}{c}{ Golden Rules } \\
\hline 1. & Strive for consistency - Aturan ini merupakan urutan \\
tindakan yang sifatnya konsisten. Konsistensi tersebut \\
berupa penggunaan dalam bentuk petunjuk, menu, \\
colour, tata letak, kapitalisasi, font, dan sebagainya. \\
\hline 2. & Enable frequent users to use shortcuts - Aturan ini \\
& untuk meningkatkan frekuensi penggunaan, yaitu \\
mengurangi jumlah interaksi dan meningkatkan \\
kecepatan interaksi. Aturan ini memungkinkan user \\
untuk sering menggunakan pintasan seperti tombol \\
fungsi, perintah-perintah yang tersembunyi, dan \\
fasilitas makro yang sangat membantu untuk user.
\end{tabular}

3. Offer informative feedback - Aturan ini menawarkan umpan balik informatif. Untuk setiap tindakan pengguna, harus ada umpan balik sistem.

4. Design dialogue to yield closure - Aturan ini menjelaskan mengenai desain dialog untuk menghasilkan penutupan. Pada aturan ini, antarmuka yang dirancang harus memiliki urutan tindakan.

5. Prevent errors - Aturan ini mengenai pencegahan kesalahan. Sebisa mungkin, sistem dirancang agar user tidak dapat membuat kesalahan serius.

6. Permit easy reversal of actions - Aturan ini mengenai memberikan kemudahan kepada pengguna untuk kembali ke tindakan sebelumnya apabila pengguna melakukan kesalahan selama berinteraksi dengan antarmuka, sehingga akan mengurangi tingkat kecemasan dari pengguna.

7. Support internal locus of control - Aturan ini menjelaskan mengenai pemberian dukungan internal secara terkontrol. Dimana pengguna dapat mengendalikan aplikasi tanpa merasa dikontrol oleh sistem karena aplikasi ini dirancang dengan menggunakan interaksi manusia dan komputer yang user friendly.

8. Reduce short-term memory load - Aturan ini menjelaskan mengenai pengurangan beban memori jangka pendek. Pada aturan ini, tampilan interface yang dibuat harus terlihat sederhana. 
B. Metode Pengumpulan Data

Adapun metode atau teknik yang dapat digunakan untuk mengumpulkan data penelitian ini, yaitu usability testing dan penyebaran kuesioner. Secara detail, kedua metode tersebut dapat dijelaskan sebagai berikut, yaitu:

\section{1) Usability Testing}

Usability testing merupakan salah satu teknik dalam evaluasi usability yang dapat digunakan untuk mengumpulkan data. Untuk mengumpulkan data, maka diperlukan task scenarios guna memandu user dalam menggunakan aplikasi, serta sebagai alat instrument untuk mengukur tingkat efektivitas dan efisiensi terhadap penggunaan aplikasi tersebut. Task scenarios merupakan kumpulan tugas yang harus dikerjakan oleh responden pada saat menggunakan aplikasi [6]. Adapun task scenario tersebut terdiri dari 10 tugas yang dapat disajikan melalui Tabel 2 berikut, yaitu:

Tabel 2. Task Scenario Usability Testing.

\begin{tabular}{cl}
\hline No & \multicolumn{1}{c}{ Task Scenarios } \\
\hline 1 . Cari dan bukalah shortcut AMPSD dan lihatlah \\
& informasi mengenai apa itu AMPSD serta cara
\end{tabular}

2. Cari dan lihatlah informasi mengenai profil pengembang AMPSD.

3. Cari dan bacalah informasi mengenai Standar Kompetensi (SK), Kompetensi Dasar (KD), dan Tujuan Pembelajaran.

4. Eksplorasikanlah seluruh isi informasi materi yang terdapat di AMPSD tersebut.

5. Anda berencana ingin lebih lagi meningkatkan pemahaman Anda terhadap materi tersebut. Kemudian Anda melihat menu tutorial pembelajaran dan tertarik untuk menonton dan mempelajarinya.

6. Ujilah kemampuan Anda melalui permainan edukatif dan lihatlah skor pencapaian Anda!

7. Evaluasilah seluruh proses pembelajaran yang telah Anda lakukan.guna mengetahui tingkat pengetahuan Anda.

8. Bacalah petunjuk cara mengerjakan soal evaluasi dengan seksama. Setelah Anda memahami petunjuk tersebut, Anda dapat memulai evaluasi tersebut.

9. Anda telah berada pada tampilan pertanyaan evaluasi. Selesaikanlah setiap pertanyaan dan ketahuilah hasil akhir evaluasi Anda!

10. Sekarang Anda telah selesai mengeksplorasi seluruh isi dari AMPSD. Anda boleh keluar dari aplikasi tersebut.

Selanjutnya, jumlah user atau peserta yang dijadikan sebagai target pengujian dalam melakukan usability testing ini, berjumlah 30 peserta yang terdiri dari dosen dan mahasiswa semester II dan IV pada Program Studi Pendidikan Fisika UNPATTI Ambon yang selanjutnya dikelompokkan menjadi kelompok dosen dan kelompok mahasiswa.

\section{2) Kuesioner}

Kuesioner merupakan teknik pengumpulan data yang dilakukan dengan cara memberi seperangkat pertanyaan atau pernyataan tertulis kepada responden untuk dijawabnya [12]. Dalam penelitian ini, kuesioner digunakan untuk mengukur tingkat kepuasan pengguna. Kuesioner yang digunakan mengacu pada System Usability Scale (SUS). SUS merupakan sebuah standar kuesioner yang mengukur kepuasaan pengguna dalam menggunakan sebuah sistem. Adapun butir-butir dari ke-10 pernyataan SUS yang telah diterjemahkan ke dalam bahasa Indonesia dan yang telah divalidasi, yang dapat divisualisasikan melalui Tabel 3 berikut [13]:

Tabel 3. Standar Kuesioner System Usability Scale (SUS).

No Butir Pernyataan

1. Saya berpikir akan menggunakan sistem ini lagi.

2. Saya merasa sistem ini rumit untuk digunakan.

3. Saya merasa sistem ini mudah untuk digunakan.

4. Saya membutuhkan bantuan dari orang lain atau teknisi dalam menggunakan sistem ini.

5. Saya merasa fitur-fitur sistem ini berjalan dengan semestinya.

6. Saya merasa ada banyak hal yang tidak konsisten (tidak serasi) pada sistem ini.

7. Saya merasa orang lain akan memahami cara menggunakan sistem ini dengan cepat.

8. Saya merasa sistem ini membingungkan.

9. Saya merasa tidak ada hambatan dalam menggunakan sistem ini.

10. Saya perlu membiasakan diri terlebih dahulu sebelum menggunakan sistem ini.

\section{Metode Analisis Data}

Teknik analisis data yang digunakan dalam penelitian ini adalah analisis deskriptif yang dianalisis secara kuantitatif dan kualitatif. Adapun penjelasan mengenai kedua analisis data tersebut, yaitu sebagai berikut:

\section{1) Analisis Data Kuantitatif}

Analisis terhadap data kuantitatif dalam penelitian ini diperoleh melalui task scenarios dan pengisian kuesioner SUS. Selanjutnya hasil yang terdapat pada task scenarios tersebut, kemudian diolah dan digunakan untuk menganalisis tingkat efektivitas dan efisiensi aplikasi sedangkan hasil pengisian kuesioner SUS digunakan untuk menganalisis tingkat kepuasan pengguna.

\section{a) Analisis Efektivitas}

Analisis terhadap tingkat efektivitas dapat diukur berdasarkan tingkat keberhasilan user dalam menyelesaikan tugas. Adapun parameter usability yang dapat digunakan untuk mengukur tingkat kesuksesan (Success Rate) user menyelesaikan tugas, yaitu [14]:

$$
S R=((S+(P S \times 0,5)) / T) \times 100 \%
$$


Di mana $S R=$ Success Rate; $S=$ Success; $P S=$ Partial Success; dan $T=$ Task

Dalam penelitian ini, hasil pengukuran tingkat kesuksesan tersebut kemudian diinterpretasikan dengan berpatokan pada Standar Acuan Litbang Depdagri tahun 1991 guna mengetahui tingkat efektivitas seperti yang terlihat pada Tabel 4 berikut [15]:

Tabel 4. Standar Ukuran Efektivitas.

\begin{tabular}{rll}
\multicolumn{1}{c}{ No } & \multicolumn{1}{c}{ Rasio Efektivitas } & \multicolumn{1}{c}{ Tingkat Pencapaian } \\
\hline 1 & $<40 \%$ & Sangat Tidak Efektif \\
\hline 2 & $40 \%-59,99 \%$ & Tidak Efektif \\
\hline 3 & $60 \%-79,99 \%$ & Cukup Efektif \\
\hline 4 & $\geq 80 \%$ & Sangat Efektif \\
\hline
\end{tabular}

\section{b) Analisis Efisiensi}

Analisis terhadap tingkat efisiensi dapat diukur berdasarkan waktu tugas, yaitu waktu (dalam detik dan/atau menit) yang diperlukan user untuk menyelesaikan setiap tugas dengan sukses [16]. Selanjutnya, terdapat parameter usability yang dapat digunakan untuk mengukur tingkat efisiensi berdasarkan lamanya waktu yang dibutuhkan user untuk menyelesaikan setiap tugas tersebut yaitu dengan menggunakan Efisiensi Berbasis Waktu (Time-Based Efficiency) yang dirumuskan sebagai berikut, yaitu [16]:

$$
T B E=\frac{\sum_{j=1}^{R} \sum_{i=1}^{N} \frac{n_{i j}}{t_{i j}}}{N R}
$$

Di mana $T B E=$ Time Based Efficiency; $N=$ jumlah total tugas (goals); $R=$ jumlah pengguna; $n_{i j}=$ hasil tugas $i$ oleh pengguna $j$ di mana jika pengguna berhasil menyelesaikan tugas maka $\mathrm{N}_{\mathrm{ij}}=1$, jika tidak maka $\mathrm{N}_{\mathrm{ij}}=0$; dan $t_{i j}=$ waktu yang dihabiskan oleh pengguna $j$ untuk menyelesaikan tugas I (jika tugas tidak berhasil diselesaikan, maka waktu diukur hingga saat pengguna berhenti dari tugas).

Oleh karena analisis efisiensi diukur berdasarkan waktu tugas, maka hasil pengukuran tersebut dilihat melalui ratarata kecepatan waktu (cepat atau tidaknya) user menyelesaikan setiap tugas yang diberikan. Selanjutnya hasil pengukuran tersebut diinterpretasikan menggunakan range waktu pada indikator time behavior yang dapat digunakan untuk menentukan lama atau tidaknya user dalam yang dapat disajikan melalui Tabel 5 berikut [15]:

Tabel 5. Interval Waktu pada Indikator Time Behavior.

\begin{tabular}{rll}
\hline No & \multicolumn{1}{c}{ Lamanya Waktu } & \multicolumn{1}{c}{ Kualifikasi } \\
\hline 1. & 1 menit -5 menit & Sangat Cepat \\
\hline 2. & 6 menit -10 menit & Cepat \\
\hline 3. & 11 menit -15 menit & Lambat \\
\hline
\end{tabular}

\section{c) Analisis Kepuasan Pengguna}

Analisis terhadap tingkat kepuasan pengguna dalam usability testing, diukur dan dianalisis menggunakan kuesioner SUS yang disebarkan kepada user setelah user menyelesaikan tugas. Kuesioner SUS terdiri dari 10 pernyataan di mana setiap pernyataan menggunakan skala Likert sebanyak lima sampai tujuh buah skala. Skala Likert digunakan untuk mengukur sikap, pendapat, dan persepsi seseorang atau sekelompok orang tentang fenomena sosial [12]. Penggunaan skala Likert dalam penelitian ini menggunakan lima buah skala dengan ketentuan sebagai berikut, yaitu 1 = Sangat Tidak Setuju (STS), 2 = Tidak Setuju (TS), 3 = Ragu-Ragu (RG), 4 = Setuju (S), dan 5 = Sangat Setuju (SS) yang kemudian dilambangkan dengan gambar smileyometer guna membantu user mengekspresikan kepuasan mereka terhadap aplikasi media pembelajaran tersebut.

\begin{tabular}{|ccccc|}
$\qquad$ & $\ddots$ & $\ddots$ & $\Theta$ & $\Theta$ \\
$(1=\mathrm{STS})$ & $(2=\mathrm{TS})$ & $(3=\mathrm{RG})$ & $(4=\mathrm{S})$ & $(5=\mathrm{SS})$ \\
\hline
\end{tabular}

Gambar 1. Smileyometer yang digunakan pada Kuesioner.

Hasil pengukuran berdasarkan kuesioner SUS tersebut, kemudian diinterpretasikan berdasarkan perbandingan skor SUS berikut, yaitu [17]:

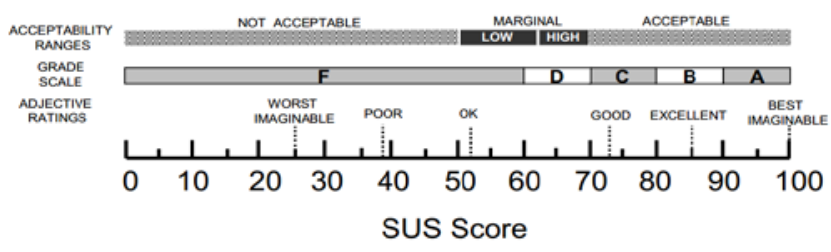

Gambar 2. Rating Scale SUS Scores.

2) Analisis Data Kualitatif

Analisis terhadap data kualitatif dalam penelitian ini dapat diperoleh melalui kegiatan usability testing yaitu mengidentifikasi target pengujian yang kemudian dilanjutkan dengan menyebarkan task scenarios untuk dikerjakan dan diselesaikan oleh responden. Hasil dari data-data tersebut kemudian dianalisis secara manual dengan mengidentifikasi masalah-masalah yang ditemukan. Kemudian berdasarkan permasalahan yang ditemukan tersebut, selanjutnya dirangkum dan dibuatkan rekomendasi perbaikan dan menghasilkan prototype guna pengembangan selanjutnya.

D. Alur Penelitian

Adapun langkah-langkah dalam penelitian ini, yang dapat divisualisasikan melalui Gambar 3 berikut, yaitu:

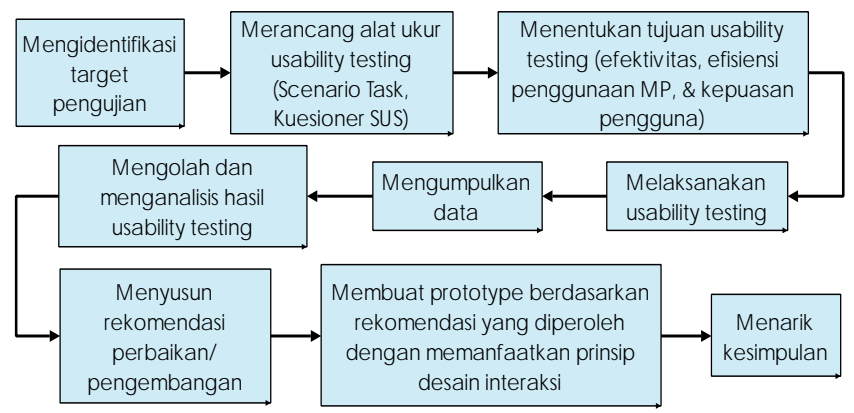

Gambar 3. Diagram Alur Penelitian 


\section{HASIL DAN PEMBAHASAN}

A. Analisis Deskriptif

1) Identifikasi Target Pengujian

Penentuan user sebagai target pengujian dalam evaluasi usability, merupakan salah satu komponen penting dalam melakukan usability testing. Identifikasi terhadap user untuk dijadikan sebagai target dalam penelitian ini adalah user yang diidentifikasikan sebagai dosen dan mahasiswa semester II dan IV pada Program Studi Pendidikan Fisika UNPATTI Ambon serta pernah menggunakan sistem atau aplikasi media pembelajaran dengan tingkat penggunaan yang berbeda, yaitu sering dan jarang menggunakan aplikasiaplikasi tersebut. Berdasarkan hasil analisis yang dilakukan, diperoleh jumlah user sebagai responden atau target dalam pengujian ini berjumlah 30 peserta dengan rincian peserta terdiri dari empat orang dosen dan 26 orang mahasiswa yang selanjutnya dikelompokkan menjadi kelompok dosen dan mahasiswa yang secara detail dapat divisualisasikan melalui Tabel 6 berikut, yaitu:

Tabel 6. Hasil Identifikasi Target Pengujian.

\begin{tabular}{lrrrr}
\hline \multirow{2}{*}{ Kriteria } & \multicolumn{4}{c}{ Tingkat Penggunaan } \\
\cline { 2 - 5 } & Sering & Persentase & Jarang & Persentase \\
\hline Dosen & 2 & $12 \%$ & 2 & $15 \%$ \\
\hline Mahasiswa & 15 & $88 \%$ & 11 & $85 \%$ \\
\hline Jumlah & $\mathbf{1 7}$ & $\mathbf{1 0 0 \%}$ & $\mathbf{1 3}$ & $\mathbf{1 0 0 \%}$ \\
\hline
\end{tabular}

2) Analisis Data Usability Testing

a) Analisis Efektivitas

Analisis terhadap tingkat efektivitas, diukur berdasarkan tingkat kesuksesan user dalam menyelesaikan tugas yang diberikan. Berdasarkan hasil pengukuran yang dilakukan, diperoleh hasil success rate yang hasil perhitungannya telah diinterpretasikan berdasarkan standar ukuran efektivitas (Tabel 4) yang selanjutnya dapat disajikan melalui Tabel 7 berikut, yaitu:

Tabel 7. Interpretasi Hasil Perhitungan Success Rate.

\begin{tabular}{crl}
\hline Kelompok & Success Rate & Tingkat Pencapaian \\
\hline Dosen & $100 \%$ & Sangat Efektif \\
\hline Mahasiswa & $94 \%$ & Sangat Efektif \\
\hline Rata-Rata & $\mathbf{9 7 \%}$ & Sangat Efektif \\
\hline
\end{tabular}

Berdasarkan Tabel 7 dapat dilihat bahwa perhitungan success rate pada kelompok dosen memperoleh tingkat kesuksesan sebesar $100 \%$ dengan tingkat pencapaiannya, yaitu sangat efektif. Sementara itu pada kelompok mahasiswa, diperoleh tingkat kesuksesan sebesar 94\% yang juga memiliki tingkat pencapaian, yaitu sangat efektif.

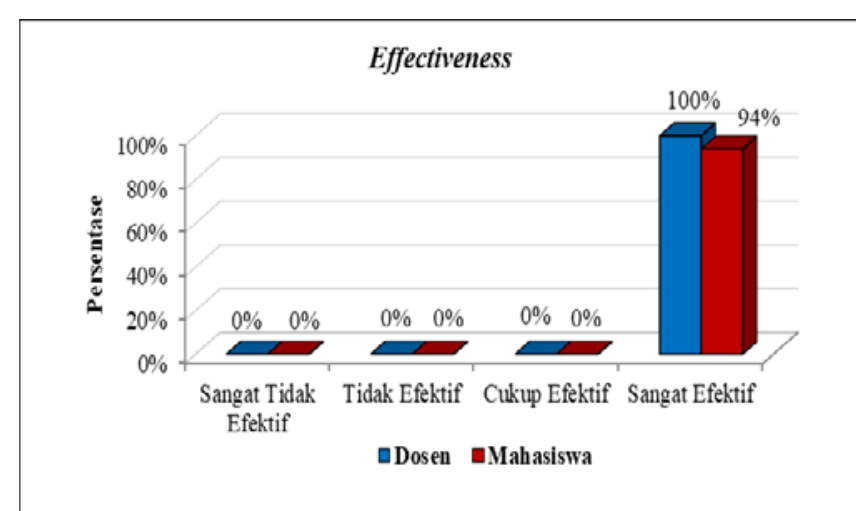

Gambar 4. Persentase Skor Pencapaian Efektivitas.

Berdasarkan hasil pengukuran terhadap tingkat kesuksesan user baik pada kelompok dosen dan mahasiswa, diperoleh rata-rata success rate sebesar 97\% dengan tingkat pencapaiannya adalah sangat efektif. Hal ini sesuai dengan standar acuan penilaian (Tabel 4) yang digunakan sehingga dapat disimpulkan bahwa AMPSD sudah efektif dari segi efektivitas penggunaannya dan memiliki tingkat efektivitas usability yang baik.

\section{b) Analisis Efisiensi}

Analisis terhadap tingkat efisiensi, diukur berdasarkan lamanya waktu yang dibutuhkan user baik pada kelompok dosen maupun kelompok mahasiswa dalam menyelesaikan setiap tugas yang diberikan. Secara rata-rata, hasil analisis terhadap efisiensi lamanya waktu dalam menyelesaikan tugas pada AMPSD, dapat disajikan melalui Tabel 8 berikut, yaitu:

Tabel 8. Rerata Waktu Penyelesaian Setiap Task Scenarios

\begin{tabular}{lll} 
Kelompok & $\begin{array}{l}\text { Rata-Rata Time } \\
\text { Based Efficiency }\end{array}$ & $\begin{array}{c}\text { Tingkat Pencapaian } \\
\text { Ind. Time Behavior }\end{array}$ \\
\hline Dosen & 0,07 goals/sec & Sangat Cepat \\
\hline Mahasiswa & 0,14 goals/sec & Sangat Cepat \\
\hline
\end{tabular}

Berdasarkan Tabel 8 dapat dilihat bahwa rata-rata waktu yang dibutuhkan user baik pada kelompok dosen maupun mahasiswa dalam menyelesaikan setiap tugas dikategorikan dalam indikator time behavior dengan tingkat pencapaian sangat cepat. Hal ini sesuai dengan yang jelaskan oleh Nielson yang kemudian disampaikan oleh Rahadi dalam penelitiannya yang menjelaskan bahwa efficiency diukur berdasarkan kecepatan mengerjakan tugas tertentu setelah mempelajari desain tersebut [18]. Dengan kata lain, efficiency menjelaskan seberapa cepat pengguna dapat menyelesaikan tugas-tugas yang ada saat mereka pertama kali mempelajari sistem tersebut [18].

Adapun hasil rerata tingkat pencapaian user baik pada kelompok dosen maupun mahasiswa terhadap setiap tugas yang diselesaikan yang dapat divisualisasikan melalui Gambar 5 berikut, yaitu: 


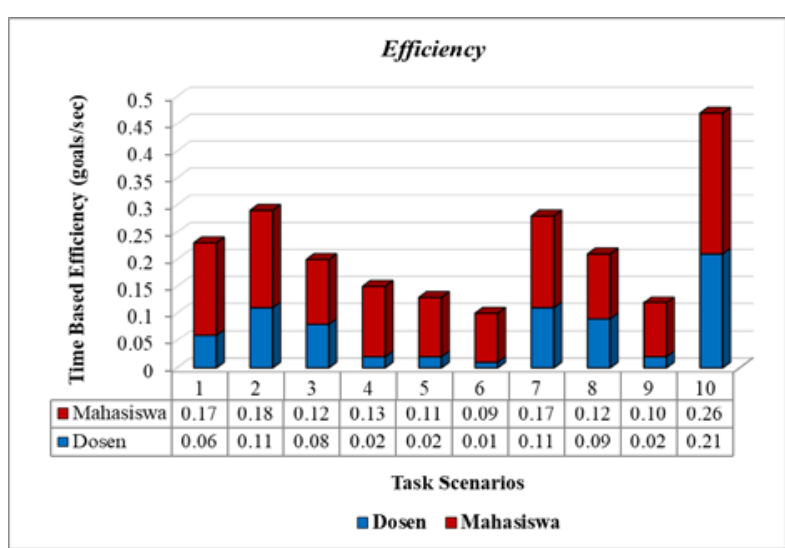

Gambar 5. Rata-Rata Lamanya Waktu Penyelesaian Tugas.

Berdasarkan hasil pengukuran terhadap tingkat efisiensi , tersebut, maka dapat disimpulkan bahwa AMPSD sudah efisien dari segi efisiensi waktu penggunaannya.

c) Analisis Kepuasan Pengguna

Analisis terhadap kepuasan pengguna, diperoleh melalui data kuesioner SUS yang dikumpulkan. Selanjutnya, analisis berdasarkan persentase jumlah responden yang menyatakan menerima maupun tidak menerima aplikasi MP Statistika Dasar, dapat ditunjukkan melalui Tabel 9 berikut, yaitu:

Tabel 9. Persentase Acceptability Ranges Jumlah Responden.

\begin{tabular}{rllrr}
\hline No & $\begin{array}{l}\text { Acceptability } \\
\text { Ranges }\end{array}$ & $\begin{array}{c}\text { Rentang } \\
\text { Skor SUS }\end{array}$ & $\begin{array}{c}\text { Jumlah } \\
\text { Responden }\end{array}$ & $\begin{array}{c}\text { Persen } \\
\text {-tase }\end{array}$ \\
\hline 1. & $\begin{array}{l}\text { Not } \\
\text { Acceptable }\end{array}$ & $0-50$ & 1 & $3 \%$ \\
\hline 2. & Marginal & $50-70$ & 8 & $27 \%$ \\
\hline 3. & Acceptable & $70-100$ & 21 & $70 \%$ \\
\hline \multicolumn{2}{r}{ Total } & & $\mathbf{3 0}$ & $\mathbf{1 0 0 \%}$ \\
\hline
\end{tabular}

Berdasarkan Tabel 9 dapat dilihat bahwa dari 30 responden yang diuji kepuasannya, terdapat satu responden (3\%) yang menolak (not acceptable) AMPSD. Berdasarkan hasil analisis yang dilakukan, diketahui bahwa satu responden yang tidak menerima ataupun menunjukkan ketidakpuasan terhadap aplikasi tersebut, berasal dari kelompok mahasiswa dengan ID M10. Hal ini terlihat pada hasil rekapitulasi pada task scenarios, yaitu bahwa pada saat melakukan 10 tugas, terdapat empat tugas yang dirasakan responden tersebut sulit untuk dilakukan, yaitu pada task 4, task 5, task 7, dan task 8. Selain itu, juga terlihat pada hasil pengisian kuesioner SUS yang secara keseluruhan menyatakan bahwa responden tersebut tidak menunjukkan kepuasan maupun menerima AMPSD. Namun, responden tersebut memberikan rekomendasi/saran agar aplikasi tersebut harus lebih disederhanakan lagi sehingga aplikasi tersebut lebih mudah digunakan dan dapat dipahami oleh pengguna.

Adapun hasil perhitungan rata-rata skor SUS terhadap kepuasan pengguna baik pada kelompok dosen dan mahasiswa, yang telah diinterpretasikan hasilnya berdasarkan Rating Scale SUS Scores pada Gambar 2 yang disajikan dalam Tabel 10 berikut:
Tabel 10. Interpretasi Hasil Perhitungan Rata-Rata Skor SUS

\begin{tabular}{lrlll}
\hline Kelompok & $\begin{array}{c}\text { Rerata } \\
\text { Skor } \\
\text { SUS }\end{array}$ & $\begin{array}{c}\text { Adjective } \\
\text { Ratings }\end{array}$ & $\begin{array}{c}\text { Grade } \\
\text { Scale }\end{array}$ & $\begin{array}{c}\text { Acceptability } \\
\text { Ranges }\end{array}$ \\
\hline Dosen & 85 & Good & B & Acceptable \\
\hline Mahasiswa & 70.29 & Ok & C & Acceptable \\
\hline
\end{tabular}

Tabel 10 menunjukkan bahwa hasil perhitungan rata-rata skor SUS terhadap kepuasan pengguna pada kelompok dosen, diperoleh skor sebesar 85 dengan Adjective Rating yaitu Good, sehingga sistem AMPSD dinyatakan Acceptable. Sementara itu, pada kelompok mahasiswa, diperoleh rata-rata hasil perhitungan SUS dengan skor sebesar 70,29 dengan Adjective Rating yaitu Ok, sehingga sistem aplikasi tersebut juga dinyatakan Acceptable.

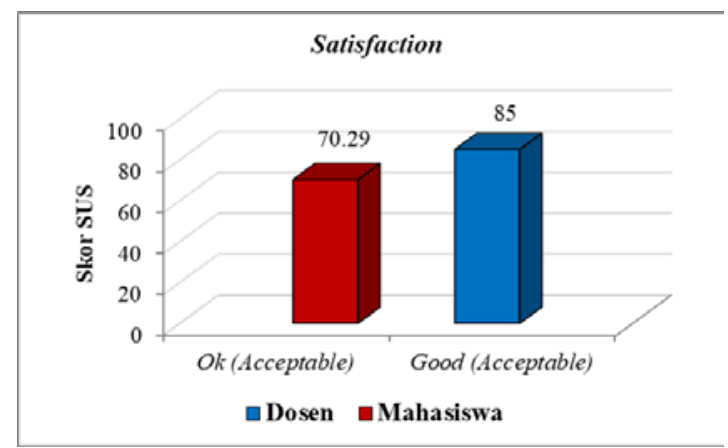

Gambar 6. Rata-Rata Hasil Perhitungan Skor SUS.

Dengan demikian, dapat disimpulkan bahwa AMPSD dapat diterima (Acceptable) baik pada kelompok dosen dan mahasiswa serta menunjukkan kepuasan mereka terhadap aplikasi tersebut dengan Adjective Rating yang diperoleh, yaitu $O k$ dan Good. Walaupun secara individu, terdapat satu responden yang tidak menerima ataupun menunjukkan ketidakpuasan terhadap aplikasi tersebut.

\section{B. Temuan dan Rekomendasi Perbaikan \\ 1) Temuan-Temuan}

Berdasarkan hasil analisis usability testing yang diperoleh, maka dapat dikatakan bahwa evaluasi yang dilakukan terhadap AMPSD telah memenuhi kriteria usability yaitu efektivitas dan efisiensi serta kepuasan pengguna dalam menggunakan aplikasi tersebut. Namun berdasarkan analisis kualitatif yang dilakukan secara manual melalui hasil task scenarios dan kuesioner SUS, ditemukan dua responden dari kelompok mahasiswa dengan ID yaitu M03 dan M05 yang mengemukakan bahwa fungsi pada halaman menu video pembelajaran tidak menunjukan fungsinya dengan benar. Menurut mereka, pada bagian video pembelajaran seringkali hanya terdapat suara (audio), namun tampilan gambar videonya tidak muncul. Adapun bentuk temuan permasalahan yang disampaikan oleh kedua responden tersebut, yaitu sebagai berikut:

M03 : "MP Statistika Dasar yang dipakai sangat mudah dan gampang untuk dipahami akan tetapi program tersebut harus dirancang agar lebih 
menarik banyak peminat karena program tersebut masih terlihat biasa-biasa saja karna sistemsistem pada program tersebut juga dapat ditemukan pada Microsoft Power Point. Selain itu pada bagian video tutorial seringkali hanya terdengar suara (audio) tanpa adanya gambar tampilan video"

M05 : "MP Statistika Dasar mudah, cepat dipahami tetapi pada video tutorial, suaranya ada tetapi tampilan gambarnya tidak ada”

2) Rekomendasi Perbaikan

Rekomendasi yang diberikan oleh responden guna memperbaiki sistem dari AMPSD untuk menjadi lebih baik lagi, yaitu perlu dirancang kembali sistemnya agar lebih memudahkan user dan tidak menimbulkan kejenuhan selama user menggunakan aplikasi tersebut. Beberapa rekomendasi tersebut terkait hal tersebut diantaranya, yaitu:

a) Rekomendasi Secara Umum

Secara umum, rekomendasi yang diberikan terkait dengan penggunaan background pada tampilan aplikasi, penambahan music/instrument, serta warna tombol/item menu, yang direkomendasikan oleh delapan responden. Menurut responden, untuk tampilan wallpaper/background, ada baiknya menggunakan gambar yang background-nya memiliki unsur statistika. Selain itu, responden juga merekomendasikan untuk menambahkan instrument atau music dengan tujuan untuk menghilangkan kejenuhan user. Hal terakhir yang direkomendasikan oleh reponden yaitu tombol pada masing-masing item menu sebaiknya menggunakan tombol dengan warna yang sedikit terang agar tampilan tombol menu menjadi lebih menarik dan jelas.

b) Rekomendasi terhadap Game Education

Rekomendasi ini disampaikan oleh tiga responden terkait dengan tampilan maupun konten pada halaman game education. Responden merekomendasikan agar game education perlu dibuat berdasarkan tingkat kesukaran permainan yaitu per level (level mudah - level sulit). Selain itu, pada konten game education, responden juga merekomendasikan untuk menambahkan permainan lainnya seperti volleyball dan golf dan juga menambahkan instrument agar user lebih tertarik terhadap permainanpermainan tersebut.

\section{c) Rekomendasi terhadap Materi \& Evaluasi}

Rekomendasi selanjutnya terkait dengan tampilan dan konten pada halaman materi yang diperoleh dari empat responden. Pada tampilan materi, responden merekomendasikan untuk menggunakan fitur-fitur education, serta pemakaian rumusnya harus menggunakan fitur atau ikon yang lebih bagus. Selain itu, juga perlu menambahkan materi-materi lainnya selain materi pada ukuran pemusatan dan juga menambahkan contoh-contoh soal. Selanjutnya, responden juga merekomendasikan pada halaman latihan soal, perlu dibuatkan pilihan jawaban untuk user memilih jawaban yang benar dan mengetahui jawaban mana yang salah serta mengetahui penjelasan maupun cara menyelesaikan soal-soal tersebut. Sementara itu, hal terakhir yang direkomendasikan oleh responden yaitu terkait dengan halaman evaluasi yaitu agar ditambahkannya soal-soal dalam melakukan evaluasi.

\section{Prototype Perbaikan}

Berdasarkan rekomendasi-rekomendasi yang diperoleh, dibuatkan prototype perbaikan yang disusun menggunakan prinsip-prinsip desain interaksi (interaction design) yaitu delapan aturan emas Shneiderman (Shneiderman's 8 Golden Rules of Interface Design) sebagai dasar perubahan guna menjadikan aplikasi tersebut menjadi suatu aplikasi yang mudah digunakan oleh user, memiliki kualitas yang tinggi, dan menjadi sistem interaksi yang baik antara manusia dan computer. Adapun prototype hasil perbaikan yang dilakukan, yaitu sebagai berikut:

Tabel 11. Prototype Perbaikan menggunakan Prinsip Desain Interaksi.

\section{Golden Rules - Prototype}

\section{Strive for Concistensy:}

a. Sebelum Perbaikan. Berdasarkan aturan pertama, kekonsistensi pada tampilan prototype sebelumnya tidak terlihat pada penggunaan background yang sama untuk setiap tampilan halaman aplikasi. Berdasarkan rekomendasi dari user bahwa penggunaan background sebaiknya menggunakan background yang memiliki unsur statistika.

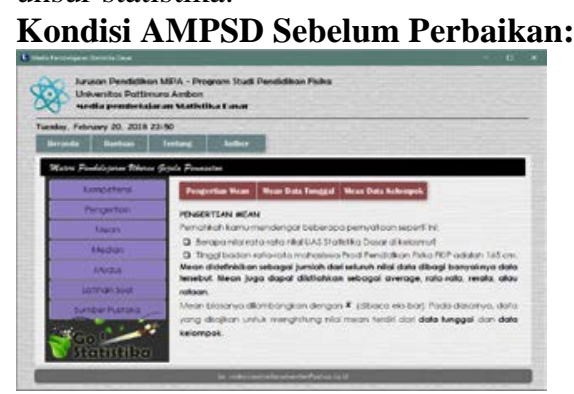

b. Sesudah Perbaikan. Setelah perbaikan, konsistensi AMPSD dapat dilihat pada setiap tindakan penggunaan aplikasi, di mana setiap halaman interface aplikasi menggunakan background/ wallpaper yang senada dan identik dengan statistika. Selain itu, juga dapat dilihat pada ukuran font dan warna font yang disesuaikan dengan background aplikasi. Selanjutnya, kekonsistensi juga terdapat pada bentuk tombol-tombol yang sama untuk tiap menu/ sub menu.

\section{Prototype Setelah Perbaikan:}

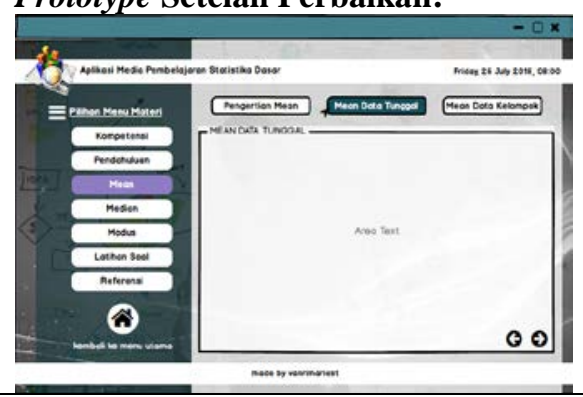




\section{Golden Rules - Prototype}

2. Enable frequent users to use shortcuts:

a. Sebelum Perbaikan. Berdasarkan aturan kedua, AMPSD dibuatkan shortcut untuk mudah digunakan. Namun, user merekomendasikan agar sepenuhnya menggunakan fitur atau ikon education.

Kondisi AMPSD Sebelum Perbaikan:

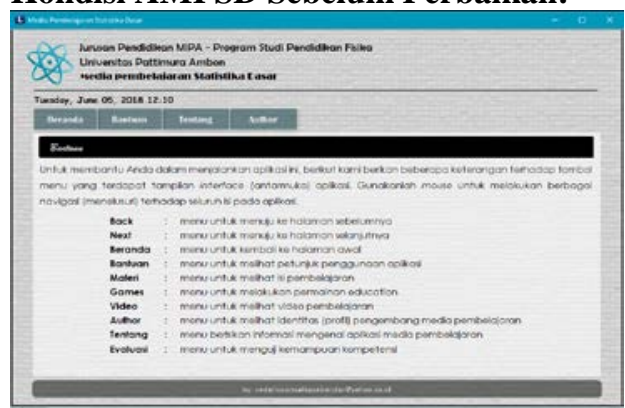

b. Sesudah Perbaikan. Pada tampilan prototype aplikasi, dibuatkan shortcut yang disertai dengan penggunaan fitur atau ikon-ikon yang menarik, sehingga dapat digunakan user secara cepat untuk mengetahui dan melihat isi dari halaman yang dituju, diantaranya, yaitu seperti shortcut tombol menu utama dan sub menu, serta shortcut tombol untuk kembali ke halaman utama. Prototype Setelah Perbaikan:

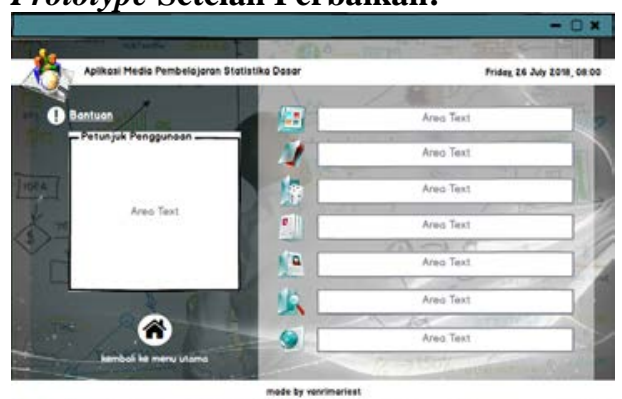

3. Offer informative feedback:

a. Sebelum Perbaikan. Berdasarkan aturan ketiga, kondisi ini terlihat pada tampilan halaman latihan soal di mana pada tampilan tersebut hanya menampilkan informasi berupa bentuk soal.

Kondisi AMPSD Sebelum Perbaikan:

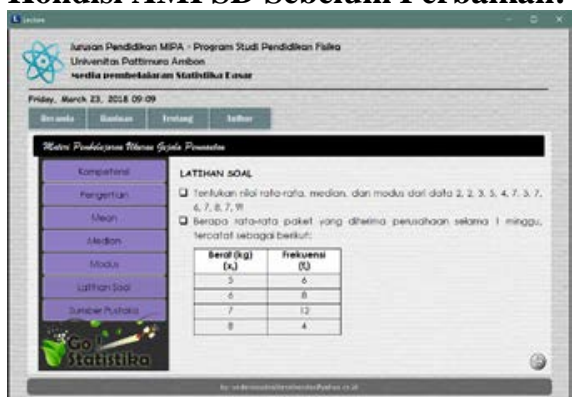

b. Sesudah Perbaikan. Berdasarkan prototype perbaikan, feedback yang informatif pada halaman latihan soal dibuatkan menu pilihan kepada user untuk dapat memilih jawaban yang dianggap benar kemudian dapat mengecek jawaban tersebut. Selanjutnya, sistem akan memberikan pop-up yang menunjukkan informasi jawaban yang benar dan salah. Selain itu, user juga

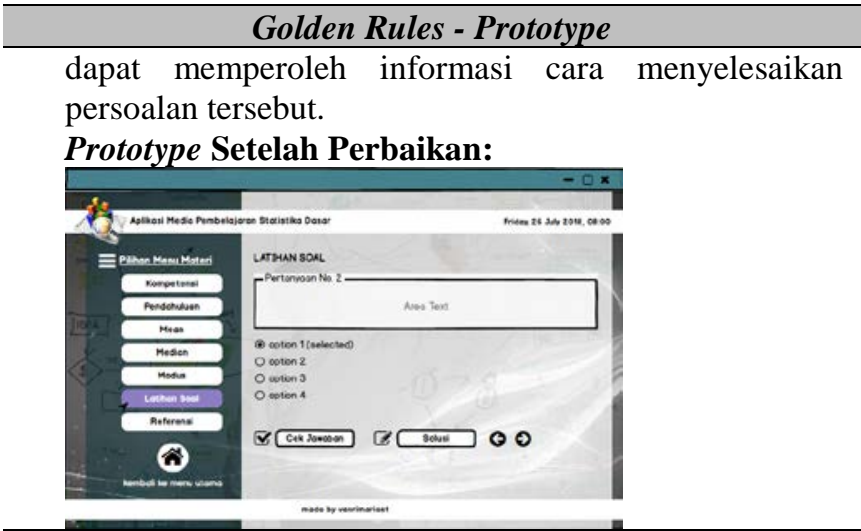

4. Design dialogue to yield closure:

a. Sebelum Perbaikan. Kondisi AMPSD dapat dilihat pada pada saat user telah selesai melakukan evaluasi. Tampilan interface setelah selesai melakukan evaluasi, hanya menampilkan skor perolehan tanpa memberikan dialog penutupan apakah ingin mencoba lagi maupun keluar dari kegiatan evaluasi.

\section{Kondisi AMPSD Sebelum Perbaikan:}

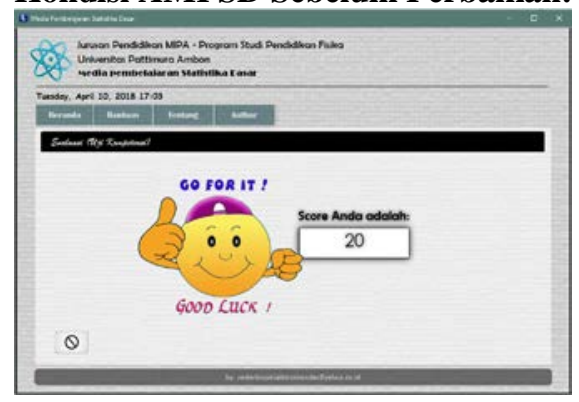

b. Sesudah Perbaikan. Berdasarkan aturan ke empat, dibuatkan rancangan dialog untuk menghasilkan penutupan setelah user menyelesaikan evaluasi di mana sistem akan menampilkan tampilan layar yang menyebutkan hasil skor perolehan user dan komentar mengenai nilai yang diperoleh. Selain itu, user juga dapat memilih untuk mencoba lagi atau cancel dari kegiatan evaluasi.

Prototype Setelah Perbaikan:

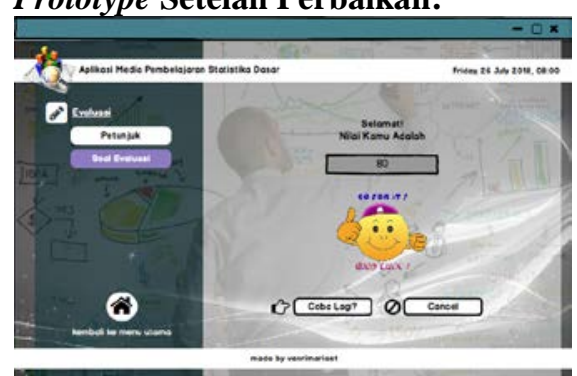

5. Offer simple error handing:

a. Sebelum Perbaikan. Kondisi AMPSD berdasarkan aturan ke lima, telah memenuhi aturan tersebut di mana kondisi ini dapat dilihat pada saat user melakukan evaluasi. Apabila user ingin melanjutkan ke pertanyaan selanjutnya dan belum menjawab pertanyaan sebelumnya, maka sistem akan memberikan penanganan kesalahan secara sederhana yaitu dengan memberikan informasi kepada user untuk menjawab 


\section{Golden Rules - Prototype}

dan mensubmit jawaban tersebut sebelum dilanjutkan ke pertanyaan berikutnya.

Kondisi AMPSD Sebelum Perbaikan:

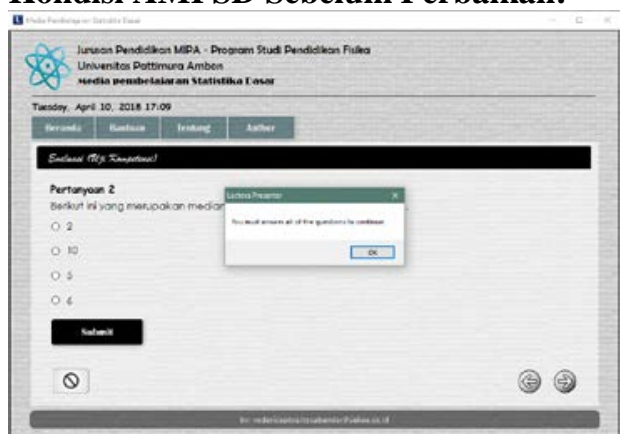

b. Sesudah Perbaikan. Prototype perbaikan hanya disusun kontennya secara sistematis dan teratur tanpa mengurangi fungsi pada saat user melakukan evaluasi.

Prototype Setelah Perbaikan:

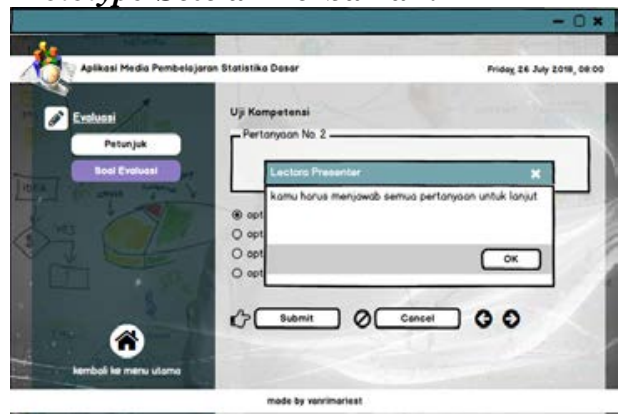

6. Permit easy reversal of actions:

a. Sebelum Perbaikan. Berdasarkan aturan ke enam, kondisi ini telah dipenuhi dengan adanya button menuju ke halaman utama (beranda) dan button kembali pada setiap halaman, guna memudahkan pengguna untuk mengeksplorasi aplikasi tanpa khawatir untuk kembali ke halaman sebelumnya.

Kondisi AMPSD Sebelum Perbaikan:

\section{Beranda}

b. Sesudah Perbaikan. Tampilan AMPSD telah memenuhi aturan ke enam, akan tetapi prototype perbaikan pada tampilan menu "Beranda" digantikan dengan icon home dengan informasi "kembali ke menu utama” sehingga lebih menarik dan memudahkan user dalam mengeksplorasi aplikasi.

Prototype Setelah Perbaikan:
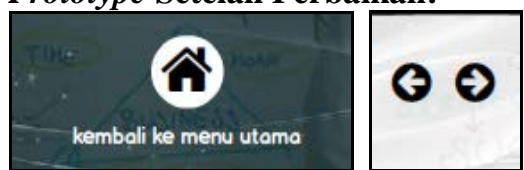

7. Support internal locus of control:

a. Sebelum Perbaikan. Tampilan interface pada halaman game education, hanya memiliki satu jenis permainan tanpa diiringi musik pengantar sehingga user memberikan rekomendasi agar menambahkan game lainnya dan disusun berdasarkan tingkatan level yang berbeda sehingga user dapat mengontrol dan memilih jenis permainan yang ingin diinginkan berdasarkan

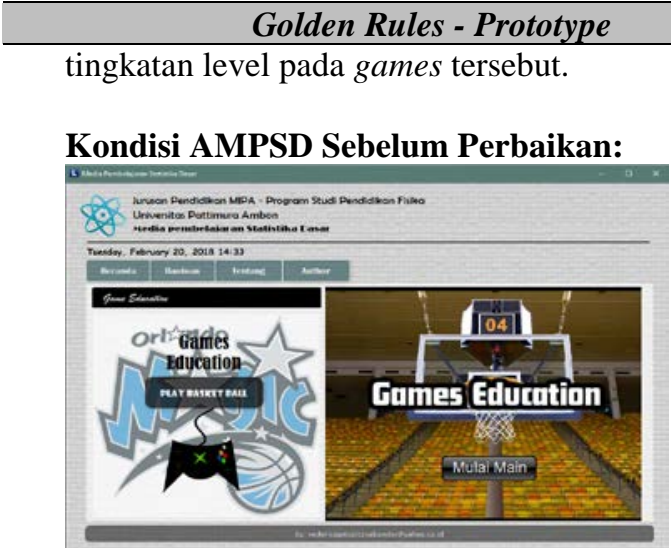

b. Sesudah Perbaikan. Berdasarkan rekomendasi user, maka prototype perbaikan pada kondisi ini dibuat dengan berbagai permainan dan tingkatan level yang juga berbeda sesuai dengan aturan ke tujuh golden rules. Dengan demikian, user dapat dengan leluasa memilih permainan mana yang ingin dimainkan. Selain itu, tampilan prototype juga dibuat dengan menarik sehingga tidak menimbulkan kejenuhan serta ditambahkan beberapa fitur tambahan sehingga user secara penuh dapat mengontrol setiap tindakan yang dilakukan selama user melakukan permainan edukatif.

\section{Prototype Setelah Perbaikan:}

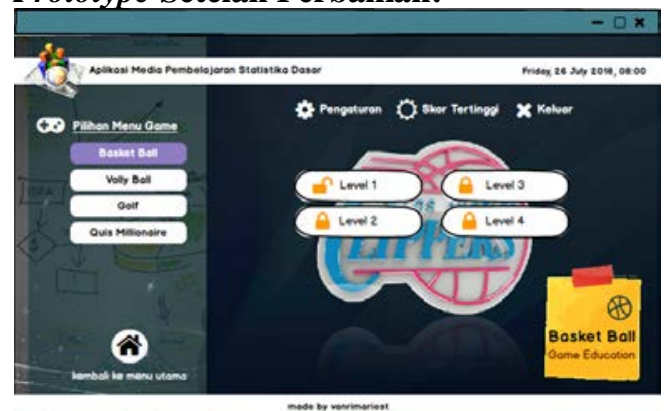

8. Reduce short-term memory load:

a. Sebelum Perbaikan. Tampilan interface pada AMPSD, sebelumnya memiliki beberapa menu tombol maupun shortcut. Akan tetapi, tidak dibuat secara menarik sehingga user merekomendasikan untuk dibuat dengan sederhana.

Kondisi AMPSD Sebelum Perbaikan:

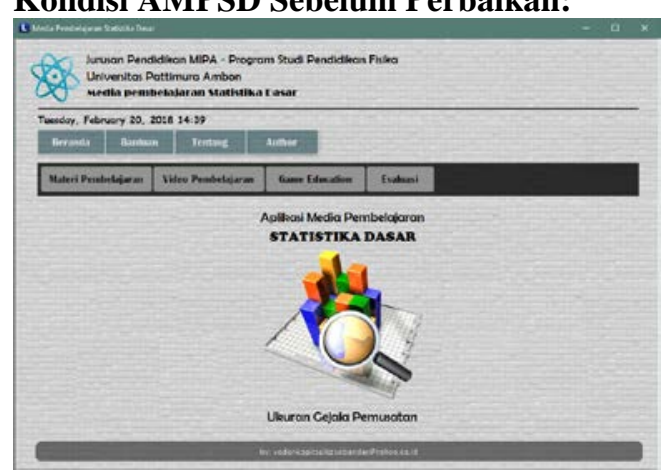

b. Sesudah Perbaikan. Berdasarkan aturan ke delapan golden rules, tampilan interface pada aplikasi dibuat sederhana dengan kekonsistenan dalam peletakan 


\section{Golden Rules - Prototype}

control content sehingga dapat memudahkan user dalam mengingat alur dari penggunaan aplikasi serta penggunaan tombol-tombol menarik atau shortcuts yang terdapat pada tampilan interface aplikasi.

\section{Prototype Setelah Perbaikan:}

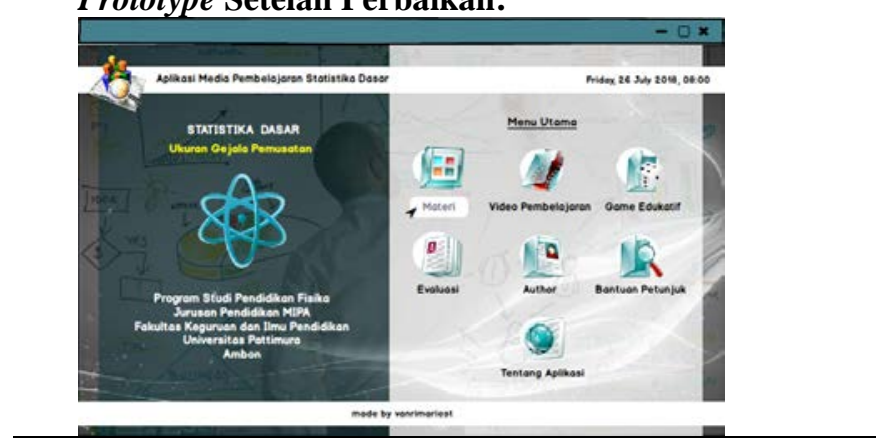

\section{KESIMPULAN}

Berdasarkan hasil evaluasi dan analisis data penelitian yang dilakukan, maka dapat disimpulkan bahwa hasil evaluasi terhadap AMPSD telah memenuhi kriteria usability, yaitu efektivitas dan efisiensi serta memberikan kepuasan pengguna dalam menggunakan aplikasi tersebut. Selanjutnya, rekomendasi yang diperoleh berdasarkan hasil evaluasi usability, yaitu terkait dengan tampilan interface dan konten yang terdapat pada halaman utama, game education, dan materi, dimana perlu dirancang kembali agar lebih memudahkan user dan tidak menimbulkan kejenuhan selama menggunakan aplikasi tersebut.

Selanjutnya, peneliti menyarankan hasil rekomendasi yang diperoleh melalui evaluasi usability, dapat dijadikan sebagai bahan masukan guna mengembangkan AMPSD secara berkelanjutan agar menjadi lebih baik dan memiliki kualitas yang tinggi serta dapat dijadikan sebagai dasar untuk pengembangan aplikasi media pembelajaran lainnya. Selain itu, peneliti juga menyarankan agar dilakukan penelitian lanjutan untuk mengetahui pengaruh dan efektivitas penggunaan aplikasi tersebut terhadap hasil belajar mahasiswa.

\section{REFERENSI}

[1] Satria, A. \& Niswatin, R. K. (2017). Android Mobile Application Untuk Kamus Pepak Bahasa Jawa.Generation Journal, 1(1).

[2] Nugroho, D. (2016). Pengembangan Media Pembelajaran Berbasis Multimedia Interaktif Pada Mata Pelajaran Teknik Elektornika Dasar di SMK Negeri 1 Bansari Temanggung. Jurnal Pendidikan Teknik Elektronika.

[3] Vebrianto, R., \& Osman, K. (2011). The Effect Of Multiple Media Instruction In Improving Students'
Science Process Skill And Achievement. Procedia Social and Behavioral Sciences, 15 (2011), 346 - 350.

[4] Handiwidjojo, W. \& Ernawati, L. (2016). Pengukuran Tingkat Ketergunaan (Usability) Sistem Informasi Keuangan Studi Kasus: Duta Wacana Internal Transaction (Duwit). JUISI, 2(1).

[5] Joo, S., Lin, S., \& Lu, K.. (2011). A Usability Evaluation Model for Academic Library Websites: Efficiency, Effectiveness and Learnability. Journal of Library and Information Studies, 9(2), 11-26.

[6] Nurhadryani, Y., Sianturi, S.K., Hermadi, I., \& Husnul, K. (2013). Usability Testing to Enhance Mobile Application User Interface. Jurnal Ilmu Komputer AgriInformatika, 2(2), 83 - 93.

[7] Rubin, J. \& Chisnell, D. (2008). Usability Testing: How to Plan, Design, and Conduct Effective Tests (2nd ed). Indianapolis: Wiley Publishing.

[8] Usability.gov. (n.d). What \& Why of Usability: Usability Evaluation Basics. Diakses dari: https://www.usability.gov/what-and-why/usabilityevaluation.html.

[9] Usability First. (nd). Usability Testing. Diakses dari: http://www.usabilityfirst.com/usabilitymethods/usability-testing/.

[10]Dharma, S. (2008). Pendekatan, Jenis, dan Metode Penelitian Pendidikan. Jakarta: Direktorat Tenaga Kependidikan Ditjen PMPTK, Departemen Pendidikan Nasional.

[11] Shneiderman, B. \& Plaisant, C. (2010). Designing the User Interface: Strategies for Effective HumanComputer Interaction (5th ed). MA: Addison-Wesley.

[12] Sugiyono. (2014). Metode Penelitian Kuantitatif, Kualitatif, dan R\&D. Bandung: Alfabeta.

[13] Sharfina, Z. \& Santoso, H. B. (2016). An Indonesian Adaptation of the System Usability Scale (SUS). ICACSIS.

[14] Nielsen, N. (2001). Success Rate: The Simplest Usability Metric. Diakses dari: https:/www.nngroup.com/articles/success-rate-thesimplest-usability-metric/.

[15] Ayu, P.D.W. (2017). Analisis Pengukuran Tingkat Efektivitas dan Efisiensi Sistem Informasi Manajemen Surat STIKOM Bali. Jurnal Sistem dan Informatika, $11(2)$.

[16] Mifsud, J. (2011). Usability Metrics - A Guide To Quantify The Usability Of Any System. Diakses dari: https://usabilitygeek.com/usability-metrics-a-guide-toquantify-system-usability/.

[17]Bangor, A., Kortum, P., \& Miller, J. (2009). Determining What Individual SUS Scores Mean: Adding an Adjective Rating Scale. Journal of Usability Studies, 4(3), $114-123$.

[18] Rahadi, D.R. (2014). Pengukuran Usability Sistem menggunakan USE Questionnaire pada Aplikasi Android. Jurnal Sistem Informasi (JSI), 1(6). 